\title{
FATHERHOOD IN ADOLESCENCE IN THE CONTEXT OF THE HEALTH SERVICES, SCHOOL AND COMMUNITY ${ }^{1}$
}

\author{
Simoní Saraiva Bordignon², Sonia Maria Konzgen Meincke ${ }^{3}$, Marilu Correa Soares ${ }^{4}$, Eda Schwartz ${ }^{5}$ Edison \\ Luiz Devos Barlem ${ }^{6}$, Valéria Lerch Lunardi ${ }^{7}$
}

\begin{abstract}
${ }^{1}$ Extracted from the dissertation - Fatherhood in adolescence in the context of the health services, school and community: a bioecologist perspective, presented to the Postgraduate Program in Nursing (PPGEnf), Universidade Federal de Pelotas (UFPel), in 2012.

2 Doctoral student of the PPGEnf of the Universidade Federal do Rio Grande (FURG). Rio Grande, Rio Grande do Sul, Brazil. E-mail: simonibordignon@gmail.com

${ }^{3}$ Ph.D in Nursing. Adjunct professor III of the PPGEnf/UFPel. Pelotas, Rio Grande do Sul, Brazil. E-mail: meinckesmk@gmail.com ${ }^{4}$ Ph.D. in Nursing. Adjunct professor II of the PPGEnf/UFPel. Pelotas, Rio Grande do Sul, Brazil. E-mail: enfmari@uol.com.br

${ }^{5}$ Ph.D. in Nursing. Associate professor I of the PPGEnf/UFPel. Pelotas, Rio Grande do Sul, Brazil. E-mail: eschwartz@terra.com.br

${ }^{6}$ Ph.D. in Nursing. Professor of the PPGEnf/FURG. Rio Grande, Rio Grande do Sul, Brazil. E-mail: ebarlem@gmail.com

${ }^{7}$ Ph.D. in Nursing. Professor of the PPGEnf/FURG. Rio Grande, Rio Grande do Sul, Brazil. E-mail: vlunardi@terra.com.br
\end{abstract}

\begin{abstract}
This study aimed to investigate the perception of the adolescent father regarding his interaction with the health services, school and community. It is an extract from the multicentric study turned Social Support Networks for Fatherhood in Adolescence, and has a qualitative, exploratory and descriptive approach. It was undertaken with 14 adolescent fathers in a university hospital. The semi-structured interviews were held six months after the birth of the child, between 2009 and 2010. Discursive textual analysis and the theoretical framework of Urie Bronfenbrenner were used for the construction of three categories: The adolescent father's perception regarding his interaction with the school; with the health services; and with the community. The adolescent fathers were shown to be receptive to formal study, and present and participative in the health services and community; the possible difficulties of interaction between the adolescent fathers and the environments studied seem to result from the lack of organization and appropriate preparation for embracing them.
\end{abstract}

DESCRIPTORS: Nursing. Fatherhood. Adolescent. Social support.

\section{PATERNIDADE NA ADOLESCÊNCIA NO CONTEXTO DOS SERVIÇOS DE SAÚDE, ESCOLA E COMUNIDADE}

\begin{abstract}
RESUMO: Objetivou-se conhecer a percepção do pai adolescente quanto à sua interação com o serviço de saúde, escola e comunidade. Trata-se de um recorte da pesquisa multicêntrica denominada Redes Sociais de Apoio à Paternidade na Adolescência, com abordagem qualitativa, exploratória, descritiva, realizado com 14 pais adolescentes em um hospital universitário. As entrevistas semiestruturadas ocorreram seis meses após o nascimento do filho, entre 2009 e 2010. Utilizou-se análise textual discursiva e referencial teórico de Urie Bronfenbrenner para construção de três categorias: Percepção do pai adolescente quanto à sua interação com a escola, com os serviços de saúde e com a comunidade. Os pais adolescentes se mostraram receptivos aos estudos formais, presentes e participativos nos serviços de saúde e comunidade. As possíveis dificuldades de interação entre os adolescentes pais e os ambientes estudados parecem decorrer da falta de organização e preparo adequado para o acolhimento destes.
\end{abstract}

DESCRITORES: Enfermagem. Paternidade. Adolescente. Apoio social.

\section{PATERNIDAD EN EL CONTEXTO DE SERVICIOS DE SALUD DEL ADOLESCENTE, ESCUELA Y LA COMUNIDAD}

RESUMEN: Este estudio tuvo como objetivo conocer la percepción del padre adolescente cuanto a su interacción con el servicio de salud, escuela y comunidad. Se trata de un recorte de la investigación multicéntrica Redes Sociales de Apoyo a la Paternidad en la adolescencia, con abordaje cualitativo, exploratorio, descriptivo, realizado con 14 padres adolescentes en un hospital universitario. Las entrevistas semiestructuradas ocurrieron seis meses después del nacimiento del hijo, entre 2009 y 2010 . Se utilizó análisis textual discursiva y referencial teórico de Urie Bronfenbrenner para la construcción de tres categorías: Percepción de los padres adolescentes cuanto a su interacción con la escuela, con los servicios de salud y la comunidad. Los padres adolescentes se mostraron receptivos a los estudios formales, presentes y participativos en los servicios de salud y comunidad. Las posibles dificultades de interacción entre los adolescentes padres y los ambientes estudiados parecen originarse de la falta de organización y preparo adecuado para el acogimiento de éstos.

DESCRIPTORES: Enfermería. Paternidad. Adolescente. Apoyo social. 


\section{INTRODUCTION}

The issue of fatherhood in adolescence has received little attention from researchers, perhaps because it is a less frequent situation compared to motherhood in this period of life. ${ }^{1}$ As a result, the role of the adolescent father in the context in which he is integrated and how he experiences this process, its meanings and responsibilities, are often unknown, both in the family and scientific ambits. ${ }^{2}$

Treating the transformations, uncertainties and responsibilities which accompany the new role of father in a negligent way can encourage a sense of alienation. ${ }^{3}$ Thus, this social posture can cause, in the adolescent fathers, greater difficulties in human development in the process of fatherhood, in the active participation in the pregnancy, and in the raising of their children and of the new family; perhaps explaining their withdrawal from the relationship. ${ }^{4-6}$

In this way, when studying fatherhood in adolescence, it is essential to visualize the person comprehensively, in his context made up of social relations and the environments in which he is integrated. In these contexts, there are emotional, cultural, religious and family influences experienced in the different levels of society (family and community), dictating how the affective, emotional and economic interactions will be established between father, mother and child. ${ }^{6}$

The co-participation of other social actors, however, is of great relevancy so as not to focus excessively on the family as the significant support network. ${ }^{7}$ In this regard, studies ${ }^{8-10}$ identify possible benefits of including the adolescent father in an articulated social network, which may be made up of the school, community and the health service itself.

The social network is understood as a system of sequential interaction made up of environments and persons who relate, directly or indirectly, with the person in development. ${ }^{11}$ In this study, these environments are understood as the school (school environment, teachers), the community (neighbors, church, sports club) and the health services (Primary Healthcare Centers (PHC); hospitals). Investigating the perception and meanings which the adolescents attribute to their social support network provides an opportunity to understand the various levels of interaction established, which could help in the experience of fatherhood.

Interaction relates to the study of processes and relationships between variables which are in constant change, and not with isolated elements. It always occurs with people, but also between these people and symbols and their contexts. ${ }^{12}$ The interactions are fundamental components in the human development; it is through them that people influence each other's behavior, these interactions being termed proximal processes. ${ }^{12}$ In this context, fatherhood is considered a social role ${ }^{13}$ and its development occurs through processes of interaction established between people and between people and their environment. These interactions ${ }^{14}$ promote the creation of meanings which define the people's specific way of thinking and acting.

It is therefore proposed to bridge a theoretical gap on the issue, given that there is a scarcity of data describing those co-responsible for pregnancy in adolescence; ${ }^{15}$ furthermore, the study aims to contribute in order to change interactions established on the part of teachers and health professionals, who often fail to address the adolescent father comprehensively and as a citizen. ${ }^{9}$ The aim is also to deepen the knowledge regarding the interactions established between the adolescent father and the social support network, providing the rationale for this study.

Moreover, based on the studies which evidenced the family as the main social support network for the adolescent father, ${ }^{8-9,16}$ the interactional processes established between the adolescent father and the school, the community and the health services as a social support network are brought into question. Considering the relevancy of interactions established between the adolescent father and the social support network, the following objective was formulated: to investigate the adolescent father's perceptions regarding his interaction with the health service, school and community.

\section{THEORETICAL FRAMEWORK}

Urie Bronfenbrenner's Bio-Ecological Model of human development has properties which involve four inter-related centers: the Process, the Person, the Context, and the Time, termed PPCT. The process is analyzed by how each person signifies his experiences and interprets the environment, with emphasis on the proximal processes, which are "a particular form of people's interaction with other people, with symbols, objects and environments, which operate over time". 12:178 Time can be understood as human development in the historical sense across generations, as this can be changed in any direction, not only for individuals, but for large segments of the population. The person involves genetically-determined characteristics and characteristics constructed in the interaction with the environment, which will influence the direction and content of the proximal processes within the context, which is made 
up of four interlinked environmental levels: the microsystem, characterized by the face-to-face interactions; the meso-system, which consists of the set of microsystems, and the interrelationships established in them; the exo-system, which relates to the environments where the person is not present, but which can affect his context; and the macrosystem, understood as ideologies, beliefs and cultures which underlie the forms of relationship established between the systems. ${ }^{12}$

For human development to be effective, it is necessary for the person to be engaged in an activity, and the interactions established must occur on a regular basis over extended periods of time, involving the person's active participation through a progressively more complex interaction. In this context, it is essential that the objects, symbols and persons present in the environment should encourage the attention, participation and interest of the person in development, based on reciprocity. ${ }^{12}$

In this way, the importance is shown of leading this study's perspective toward the meso- system, as this encompasses the community (church, sports club), health services (Primary Healthcare Center, hospital) and the school. One should not, however, fail to consider the other environments, the micro-system, the exo-system and macrosystem in the context of fatherhood in adolescence.

\section{METHODOLOGY}

This qualitative study, of the exploratory and descriptive type, was undertaken based on data previously collected in the multicentric study: "Social Support Networks for Fatherhood in Adolescence" (RAPAD, in Portuguese), financed by the National Council for Scientific and Technological Development (CNPq) under Process n. 551222/2007-7, undertaken in three university hospitals linked to public universities in three Brazilian states: Rio Grande do Sul (RS), Santa Catarina (SC) and Paraíba (PB). ${ }^{7}$ The RAPAD study was undertaken in the period December 2008 December 2010, and included two sub-studies, one quantitative and the other qualitative.

The present study used the data obtained in the qualitative sub-study, which was divided in two periods: the first, shortly after the birth of the adolescent father's child, and the second six months after the birth. This study's subjects were the adolescent fathers from the city of Pelotas-RS, selected in the RAPAD study's database, who participated in the second period of the qualitative study.

The inclusion criteria for the subjects were: to be aged between 10 and 19 years old, in line with the World Health Organization's chronological criteria of adolescence; to live within the city limits; and to accept to receive the interviewer in his home. Of the 23 adolescent fathers who participated in the first period of the RAPAD study, 14 fathers accepted to participate in the second period of the study, five were not found and four declined to be interviewed again.

Data collection was undertaken through semi-structured, recorded interviews with closed questions referent to age, family income and educational level and open questions with the intention of guiding the discussions regarding the adolescent fathers' perception in relation to their interaction with the social support network. The interviews were held in the subjects' homes six months after the birth of their son/daughter, in the period June 2009 - June 2010. The period between the first and the second interview was stipulated with the aim of investigating the father in the exercising and experiencing of fatherhood after a period of time.

The data were analyzed through discursive textual analysis, understood as a self-organized process of construction of understanding, in which new understandings emerge from a recursive sequence of three components: unitarization, the establishment of relationships, and the capturing of emergent properties. ${ }^{17}$ The unitarization was undertaken based on the deconstruction of the text, through its rigorous and in-depth reading, analyzing the text in its details, fragmenting it and emphasizing the units of meaning. The construction of categories occurred based on the establishment of relationships between the units. The last stage of this process was the capturing of the emerging properties: the metatext is the result of this process, which allowed the production of new understandings relating to the phenomena and discourses investigated. ${ }^{17}$ As discursive textual analysis presupposes that it is "impossible to see without theory; it is impossible to read and interpret without it", ${ }^{\prime 7: 15}$ this study therefore seeks support and coherence using the theoretical framework of Urie Bronfenbrenner's PPCT Model.

The RAPAD study was approved by the Ethics Committee of the Faculty of Dentistry of the Federal University of Pelotas (Opinion $n$. 007/2008). All of the participants signed the Terms of Free and Informed Consent. The ethical precepts were respected in full, and to this end, in the case of those below 18 years old, the signature of parents or guardians, who were present at the time of the interview, was also requested, so as to comply with Law n. 10,4068 of $10^{\text {th }}$ January 2002, of the Brazilian Civil Code. ${ }^{18}$ Each interview was codified using a 
fictitious name followed by a number referent to age, so as to ensure the participants' anonymity.

\section{RESULTS}

Based on the characterization of the 14 adolescent fathers interviewed, it was evidenced that six were aged 19 years old, six between 17 and 18 years old, one was 16 years old and the other, 14 years old. Seven adolescent fathers stated that they were white, five that they were black, and two, of mixed race. In relation to marital status, 13 stated that they were single, of whom seven had a partner and one was separated. In relation to employment, one father was not working and that the others were working informally. The mean monthly income mentioned was two minimum salaries. The value of the minimum salary considered in this study was $\mathrm{R} \$ 465.00$ per month. In relation to educational level, one had finished junior high school and the others had not.

Based on the analysis of the data and on Bronfenbrenner's theoretical framework, three categories were constructed a priori referent to the adolescent father's meso-system: The adolescent father's perception regarding his interaction with the school; The adolescent father's perception regarding his interaction with the health services; and The adolescent father's perception regarding his interaction with the community. It is emphasized that the same environment will never be perceived in the same way by two people, hence, the adolescent fathers did not necessarily manifest specific levels of interaction for all the environments, presenting greater emphasis on one or on another, as described below.

\section{The adolescent father's perception regarding his interaction with the school}

The adolescent fathers mentioned valuing formal education, recognized in this study as that processed within the school environment, with previously delimited content. This valuing is characterized in the accounts by the possibility of providing greater support for the raising of the children, and better living conditions for the adolescent father's family. Furthermore, the interviewees recognize the difficulties of working, studying and caring for the child, and some, even though not attending school for reasons of work, aimed to return to the classroom, a place in which they had experienced significant times.

I went back to studying when my daughter was born and finished Junior High, now I am in Senior High and I am working [...]. I went back to studying because what was I going to be able to give her, with only a junior high school education? (Lauro16).

In the evening I get home from work and I study, I go to college, and afterwards I come to see my son [...]. The teachers and the school are positive things for my future [...], but it is a little hard, working, studying and at the same time caring for my son, I feel happy. It is my son who gives me the strength to do all these activities (Carlos Alberto19).

I stopped studying [...] Because I had to work, I consider the school to be close to my day-to-day routine, I grew up studying in this college here [...] I intend to return, because I still want to study, there is a lot to learn (Ricardo19).

The recognition of the importance of studying does not come only from the adolescent father, but from the couple, which tries to be articulated such that both can achieve their objectives through formal education. They also showed - many, many times - concern with maintaining the job already acquired, emphasizing the importance of the family support in coping with and encouraging studying and caring for a child.

My wife, too, is going to return to study, except in the morning, I am going to study at night, so in the morning I will stay with my son [...] And after, at night, she stays with him. That way, if anything happens, if we study at night, my mother will care for him (Ricardo19).

[...] I want to train as an electrician, but at the moment I can't study and work because my wife is close to finishing her course, so until she graduates and can work, then I will be able to worry less, because she will be working, and then I will get a part-time job, so that I can study and work to get a qualification (Bernardo19).

Some adolescent fathers, however, reported choosing not to attend school, this being caused by school timetables coinciding with work, difficulties in caring for the child, and not liking the school environment.

[...] I didn't want to study anymore, my family wants me to study, they advised me to go back to school, in order to have a future, to help my son, quite a lot (Conrado14).

\section{The adolescent father's perception regarding his interaction with the health services}

The adolescent fathers showed commitment to the health care of their children at the Primary Healthcare Center (PHC). They claimed that they significantly follow the routine checkups, and are motivated to understand the care advised and to discuss healthy strategies to be adopted, autonomously and 
independently, although stating that at certain times, it was impossible to attend them because of work.

[...] I think that, you know, I went to all the checkups [...] Since the beginning, all of them, I always go together [...] to be with her when she gets the vaccination, to see what might happen afterwards, what symptoms may come afterwards, always asking questions (Carlos Alberto19).

[...] It was only the health clinic which helped us, as he had the beginnings of bronchitis, the doctor gave him the medicine, the nurse [...] lent him the equipment for the use of the medication [...] Whenever he gets ill I go with him to the doctor to see what is wrong with him, it was even me who went in to talk with the doctor, it was me that went, not my wife (Johnatan18).

At the clinic I usually go to nearly all the checkups. It even used to be me who took him to the health clinic, but now I don't have much time (Renato18).

Some adolescent fathers, however, reported behaviors of lack of interest in hearing and being present at the evaluation of the health of their child, demonstrating, at the same time, the lack of encouragement on the part of the health team for this adolescent. This behavior of the health team may demonstrate some of the difficulties relating to embracement on the part of the PHC.

It was only my wife who went to the checkups, so she went in and I stayed waiting, I didn't see them providing the care. I didn't want to, and also think that I wasn't allowed to. If I was, I didn't want to know, I wasn't interested in knowing (Carlos19).

I have more of a link with the clinic there, close to my mother's house, the attendance is good [...] Not much better than here, but it is better (Carlos Alberto19).

I don't have time to go, it is my wife who goes (Roberto Carlos17).

Seeking the hospital, on the other hand, was mentioned by one adolescent father in situations of problems with the child's health, mainly due to there being no interaction with the PHC.

[...] When he needs to be seen, I only take him to the Emergency Room, I don't have any link or bond with the clinic (Clóvis19).

\section{The adolescent father's perception regarding his interaction with the community}

In the adolescent fathers' accounts, it was possible to observe changes in the relationships between the people with whom the adolescent father interacted. In addition to facing judgments from the community around him, the adolescent father came to select the company he kept in terms of the well-being of his family.

In the community, everybody was against us because we were young [...] and friends keep their distance (João17).

[...] Ah, before I became a father, they used to come here, we played together, me and the lads, but now everybody keeps away, they don't come here much. And I distanced myself from some of them, because they have started using drugs (Ricardo19).

Some adolescent fathers, however, mentioned receiving support from neighbors and friends, showing the relevance of interacting reciprocally with the other, who can motivate, comfort and help in the process of experiencing fatherhood. The church is mentioned as the environment in which the family coexists with others and with itself, which is not the case with football or with the samba school, as shown in the examples reported:

[...] Everybody helped me, neighbors, friends, acquaintances, giving support - teaching me how to be a father, coming to talk and telling me what to do, telling me what I'm doing wrong (Bernardo19).

[...] In the community, we go to church, my son is baptized, we participate there (Ricardo19).

[...] Ah, I always go to football, at the gym (Carlos Alberto19).

I go to the training of the samba school (Clóvis19).

\section{DISCUSSION}

The PPCT Model aims to make it possible to investigate the person in their ecological context, through their interactions in the environments in which they live/coexist. ${ }^{12,19}$ The meso-system, therefore, is made up of the microsystems of school, community and health services, and influences and is influenced by the interactional dynamics established with the adolescent in the proximal processes, which makes it a differential in healthy human development.

Adding the phenomenon of fatherhood to the period of adolescence means experiencing a process of transformations and (re)constructions, ${ }^{4}$ in search of the identity for this man who is yet an adolescent, as well as for his family. ${ }^{20}$ The adolescent father comes to experience a new role in society. ${ }^{4}$ This process can configure interactional changes with the social support network in accordance with the socio-cultural context, historical time and stage of development of the human being and the family.

Passing from one role to another occurs at various times throughout the lifecycle, whenever a person has their position altered due to their social circle or to the roles and activities undertaken. 
These episodes of passing between roles are understood as a basic element of the process of human development, being termed ecological transition. ${ }^{11}$

In this study, the adolescent fathers interviewed mentioned that, after receiving the news that they were fathers, they had as a duty, almost on their own, the support of their children, and mentioned feeling distress and fear of not being able to fulfill this financial responsibility. In this same regard, the maturing of the adolescent who becomes a father occurs due to the necessities imposed by the logic of survival, as the economic conditions for meeting the demands and needs of the children arise, often, from his work. ${ }^{4,21}$

Changes in roles cause variations in the interactions and in how people communicate with each other; ${ }^{11}$ hence, behaviors and opinions only make sense if understood in the context in which they were constructed. This study demonstrated that the adolescent fathers interviewed experienced distinct interactions for school environments, health environments and community environments, as they expressed, in their accounts, qualitative characteristics of valuing of these environments - through recognition, responsibility and care - or of lack of valuing, through disinterest and difficulties in establishing reciprocal interactions. All these characteristics seemed to transcend generations. The adolescent seeks to adapt to the new role of father, constructing his personal characteristics added to the characteristics of the environments in which he has coexisted throughout his life.

In this reflective line of thinking, fatherhood in adolescence and the interactions established regarding the health services, school and the community confirm discussions which were preestablished socially between the man and the care with health, education and the supporting of the family, which are matters which can be perpetuated over time, socially and culturally. However, at the same time as it perpetuates opinions, it can also promote changes. ${ }^{19}$

Regarding the interaction with the school, ${ }^{10,22}$ the adolescent's lack of preparation for dealing with fatherhood makes it difficult to conciliate school, work and care for the child, making this a challenge, which results in dropping out of school being the predominant attitude among the adolescents. In this study, the interviewees had a low educational level, and the perception of the teacher as a professional who should be available for them, with the intention of supporting them, was not observed. On the other hand, they demonstrated signifying the school environment as a positive space for their future and that of their family, bearing in mind that the interviewees went to school or intended to return to formal education.

The individual experiences, and how each adolescent father applied meaning to them relates to the person's subjective characteristics, but also to the quality of the interactions established with persons, symbols and environments in the proximal processes. ${ }^{12}$ Thus, in this study, the context of fatherhood in adolescence was evidenced from another point of view, which emphasizes the dream and the search for formal education, it being observed that the recognition of the difficulties existing seems to serve as encouragement for some fathers who aim for a better future for themselves and their family.

It is appropriate to emphasize the mobilization which some adolescent couples mentioned with the aim of continuing with their studies, seeking better living conditions for the family which they were building. Parenthood in adolescence relates to how people take responsibility, that is, the father, mother and child triad, in relation to the preparation for the future, in search of improvement in their quality of life and in the matters of planning regarding the individual and family social conditions. ${ }^{10}$

It was observed that the family offered verbal encouragement and encouragement from being present in relation to returning and remaining in formal education, as with the question of the health services, as it was possible to perceive the constant presence of somebody from the family, besides the adolescent couple, in the emergency or routine consultations. There is an increase in the person's developmental strengths when the family also becomes involved in the formation of the social support network. ${ }^{11}$

In the context of the health services, the adolescent fathers in the present study showed that they attend the PHC. It was possible, however, to perceive the absence of reciprocity in the development of the interactions between the health team and the adolescent father, due to the scarcity of reports regarding the same directly with the nurse and/ or other health professional. The health services are perceived as disorganized in the sense of the inclusion of the adolescent father, both in the prenatal consultations and in assistance with the experience of fatherhood, ${ }^{1,4,6}$ which corroborates this study's findings. One can say, therefore, that the context has a key role, as it is in this that the interactions and the proximal processes occur.

The interactions between the people occur in accordance with the level of reciprocity in the relationships, in which they must be perceived as participative and active beings. In this way, the 
adolescent is not the only responsible person for the effectiveness and encouragement within the proximal processes which can occur with the health services. ${ }^{12}$ The proximal processes experienced as a source of motivation must integrate the proposal of the social support network, through the mutual interaction of the people involved, with the intention that this network should come to be part of the adolescent father's life in a significant way. These processes must not be undertaken unilaterally, as in the case of, for example, the overly-technical attendance of the prenatal or child-rearing consultation, related to the health service. Thus, the social embracement, when undertaken appropriately, can encourage the adolescent father to recognize his role with the health services. ${ }^{16}$

In relation to the adolescent fathers' interaction with the community, it was ascertained that these recognize significant changes in their coexistence with friends, due to the responsibilities imposed by fatherhood, reporting that these same responsibilities were only recognized by the community when they had to do with financial support. The church appeared as a place of family and religious socialization, in contrast with the leisure spaces such as the gym and the samba school, which seemed to establish an individualist relationship with the adolescent father. The responsibility for caring for a child and the family changes the adolescent's behavior, who comes to seek with greater emphasis those environments and people who provide experiences and situations of understanding and support which favor the development of the role of the father. Thus, the community may be understood as a promoter of human development, socialization, and the construction of identity. ${ }^{6}$

The adolescent may experience innumerable feelings, including contradictory ones, and the recognition and understanding of the new role of fatherhood do not always occur immediately, given that the role may be constructed during the experience of fatherhood. ${ }^{4,21}$ This consideration encompasses, as well as the microsystem of the family, the importance of friends, neighbors, teachers and the health team as actors who can support the adolescent in the development of the role of father, through establishing reciprocal interactions over prolonged periods of time.

It should be emphasized that observing the adolescent father comprehensively within the meso-system in which he lives allows one to confirm that this study's findings ratify that how one exercises fatherhood seems to be altered positively in the different environments, according to time and the person. This was confirmed through the participation of the adolescent fathers in the health checkups, and in their interest in understanding the guidance provided. The search for the development of their family through formal education, the recognition that - following fatherhood - individualistic thinking needs to be overcome, the concern with caring for the child, the wife and the family, also contribute to the exercising of fatherhood in a healthy and effective form.

Thus, there is the appearance of an adolescent father ${ }^{20}$ who shows great involvement and concern with education and care of the children, ceasing to exercise only the role of the father as provider. In this way, emphasis is placed on the importance of encouraging the broadening and improvement of new forms of processes of interaction, based on reciprocity, between the social support network and the adolescent father, such that the adolescents may experience fatherhood healthily.

\section{FINAL CONSIDERATIONS}

It was observed that the adolescent fathers valued formal education as a means of improving their lives and offering a more appropriate support for the development of their families. It is believed that the symbology of the theoretical qualification over time fosters the need and the desire to study. The health services mentioned by the adolescent fathers, on the other hand, were frequently related to the context of the PHC or hospital, which may be related to a deficient interaction on the part of the professionals with the adolescent father, possibly due to the difficulties of embracing the adolescent being by the health services themselves. In relation to the community, some subjects claimed that they were continuing with their leisure activities, such as playing football or attending a samba school, while others mentioned feeling excluded by their friends and finding it difficult to be accepted by the community.

According to this study's data, human development cannot be considered effective in adolescent fatherhood in all the environments which make up the meso-system, due to the lack of regularity of time and reciprocity in the interactions in the proximal processes and to the lack of interrelationship between the environments studied. However, the results obtained demonstrated that the adolescent fathers were shown to be receptive to formal education, and present and participative in the community and in the health services. As a result, difficulties in interacting with school, the health services and the community seem not to result from the adolescents in its integration in the environments studied, but 
from their appropriate organization and preparation for the embracement of these adolescents.

In this way, one can observe the need for the intervention of the nursing professionals, working with the adolescent population, seeking new actions directed towards the integration of the adolescent fathers in the health services, school and community, which can serve more effectively as a potential context for social change, in the ways of effectively strengthening and supporting the adolescent in the experience of fatherhood, through actions promoting health and education, as it is possible to establish reciprocal interactions which form a social network present in these environments.

\section{REFERENCES}

1. Hollman D, Alderman E. Fatherhood in adolescence. Pediatr Rev. 2008 Out; 29(10):364-6.

2. Levandowski D, Piccinini CA. Expectativas e sentimentos em relação à paternidade entre adolescentes e adultos. Psicol Teoria Pesq. 2006 Jan-Abr; 22(1):17-27.

3. Freitas WMF, Coelho EAC, Silva ATMC. Sentir-se pai: a vivência masculina sob o olhar de gênero. Cad Saúde Pública. 2007 Jan; 23(1):137-45.

4. Frewin K, Tuffin K, Rouch G. Managing identity: adolescent fathers talk about the transition to parenthood. N Z J Psychology. 2007 Nov; 36(3):161-7.

5. Almeida AFF, Hardy E. Vulnerabilidade de gênero para a paternidade em homens adolescentes. Rev Saúde Pública. 2007 Ago; 41(4):565-72.

6. Luz AMH, Berni NIO. Processo da paternidade na adolescência. Rev Bras Enferm. 2010 Fev; 63(1):43-50.

7. Silva MNRMO. Redes sociais Significativas na saúde mental: (des)cobrindo relações no sofrimento psíquico grave e (redes) cobrindo elos de encontro [dissertação]. Brasília (DF): Universidade de Brasília. Programa de Pós-Graduação em Psicologia Clínica; 2010.

8. Amparo DM, Galvão ACT, Alves PB, Brasil KT, Koller $\mathrm{SH}$. Adolescentes e jovens em situação de risco psicossocial: redes de apoio social e fatores pessoais de proteção. Estud Psicol. 2008 Ago; 13(2):165-74.

9. Meincke SMK, Carraro TE. Vivência da paternidade na adolescência: sentimentos expressos pela família do pai adolescente. Texto Contexto Enferm. 2009 Jan-Mar; 18(1):83-91.

10. Carvalho GM, Merighi MAB, Jesus MCP. Recorrência da parentalidade na adolescência na perspectiva dos sujeitos envolvidos. Texto Contexto Enferm. 2009 Jan-Mar; 18(1):17-24.

11. Bronfenbrenner U. A ecologia do desenvolvimento humano: experimentos naturais e planejados. Porto Alegre (RS): Artes Médicas; 1996.

12. Bronfenbrenner U. Making human beings human: bioecological perspectives on human development. Londres (UK): Sage; 2005.

13. Vasconcelos VMR. Desenvolvimento humano, psicologia e cultura. In: Silveira P, organizador. Exercício da paternidade. Porto Alegre (RS): Artes Médicas; 1998. p. 41-5.

14. Prati L, Couto MCPP, Moura A, Poletto M, Koller SH. Revisando a Inserção Ecológica: uma proposta de sistematização. Psicol Reflex Crit. 2008; 21(1):160-9.

15. Costa COM, Lima IC, Martins Júnior DF, Santos CAST, Araújo FPO, Assis DR. Gravidez na adolescência e coresponsabilidade paterna: trajetória sociodemográfica e atitudes com a gestação e a criança. Ciênc Saúde Coletiva. 2005 Jul-Set; 10(3):719-27.

16. Bueno MEN, MeinckeSMK, Schwartz E, Soares MC, Corrêa ACL. Paternidade na adolescência: a família como rede social de apoio. Texto Contexto Enferm. 2012 Jun; 21(2):313-9.

17. Moraes R, Galiazzi MC. Análise textual discursiva. Ijuí (RS): Ed. Unijuí; 2011.

18. Brasil. Lei n. 10.406, de 10 de Janeiro de 2002: Institui o novo código civil. Presidência da República. Casa Civil. Subchefia para Assuntos Jurídicos. Institui o Código Civil. Diário Oficial da União de 11 de janeiro de 2002, p. 1. 2002.

19. Narvaz MG, Koller SH. O Modelo bioecológico do desenvolvimento humano. In: Koller SH, organizador. Ecologia do desenvolvimento humano: pesquisa e intervenção no Brasil. São Paulo (SP): Casa do Psicólogo; 2004. p. 51.

20. Carraro TE, Meincke SMK, Collet N, Tavares BC, Kempfer SS. Conhecimento acerca da família do pai adolescente observado por meio do genograma. Texto Contexto Enferm. 2011; 20(spe):172-7.

21. Fernandes VS, Meincke SMK, Soares MC, Bueno MEN, Monteiro RFC, Burille A. Vivência da paternidade na adolescência. J Nurs UFPE [online]. 2011 [acesso 2012 Dez 5]. Disponível em: http:// www.revista.ufpe.br/revistaenfermagem/index. $\mathrm{php} /$ revista/article/view/1460

22. Bunting L, McAuley C. Research review: teenage pregnancy and parenthood: the role of fathers. Child Fam Soc Work. 2004 Ago; 9(3):295-303. 